\title{
Fructooligosaccharides production in aqueous system using commercial and home-made inulinase after treatment in pressurized fluids
}

\author{
M. F. SILVA ${ }^{1,4}$, D. RIGO ${ }^{1}$, V. MOSSI ${ }^{1}$, S. GOLUNSKI ${ }^{1}$,
}

\author{
G. O. KUHN ${ }^{1}$, N. S. MARCON ${ }^{1}$, R. DALLAGO ${ }^{1}$, M. A. MAZZUTTI ${ }^{2}$
}

M. V. TRES ${ }^{1}$ J. V. OLIVEIRA ${ }^{3}$, D. OLIVEIRA ${ }^{3}$, H. TREICHEL $^{4 *}$

\footnotetext{
${ }^{1}$ Department of Food Engineering, URI - Campus de Erechim, Av. Sete de Setembro, 1621, Erechim, RS, 99700-000, Brazil.

${ }^{2}$ Department of Chemical Engineering - Federal University of Santa Maria, Av. Roraima, 1000, Santa Maria, RS, 97105-900, Brazil

${ }^{3}$ Departament of Chemical and Food Engineering, Universidade Federal de Santa Catarina, UFSC, Campus Universitário, Bairro Trindade, Caixa Postal 476, 88040-900, Florianópolis, SC, Brazil

${ }^{4}$ Federal University of Fronteira Sul - UFFS, Av. Dom João Hoffman, 313, 99700-000, Erechim, RS, Brazil

Corresponding author: ${ }^{*}$ helentreichel@gmail.com
}

RESUMO - Fructoligosaccharides (FOS) are food additives with several health benefits, especially in the digestive tube, where they act as prebiotics presenting several advantages over other oligosaccharides synthesized industrially. This work is focused on the synthesis of fructooligosaccharides (FOS) from sucrose and inulin using free, immobilized and pre-treated inulinases from Kluyveromyces marxianus NRRL Y 7571 and Aspergillus niger in aqueous system. Initially, the influence of the different gases (propane, n-butane and LPG) on FOS production was investigated. The best results were achieved when both enzymes were previously treated with LPG. For the synthesis of FOS using inulinases from Aspergillus niger, $56.98 \%$ of GF2 and $8.47 \%$ of GF4, was obtained using inulin as substrate. Using inulinases from Kluyveromyces marxianus NRRL Y 7571, 4.8\% of GF2, 5.47\% of GF3 and 4.27\% of GF4 was achieved, also using inulin as substrate.

\section{INTRODUCTION}

Inulinases can be obtained from yeasts, fungus, bacteria and plants (Manzoni and Cavazzoni 1992). Special attention is given to the enzymes produced by Kluyveromyces 


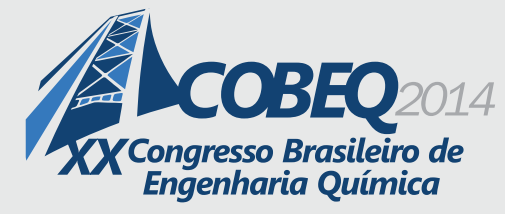

19 a 22 de outubro de 2014

Florianópolis/SC

marxianus and Aspergillus niger, that presents promising activity on the substrate sucrose and inulin (Linde et al. 2012).

These enzymes can be used in hydrolysis processes of inulin aiming at obtaining fructose syrup and fructooligosaccharides, and also in the oligosaccharides synthesis from sucrose (Risso et al. 2012).

Oligosaccharides are carbohydrates with degree of polymerization from 2 to 10 and they are present as majority components in many natural products and can also be chemistry or enzymatically produced. Nowadays, the enzymatic production starts from simple sugars, by transglycosylation or degradation of polysaccharides from vegetable, animal or microbial origin (Treichel et al. 2011).

Depending on the connections done by the residual monosaccharides, different series of FOS can be formed. ${ }^{1}$ F-FOS contain $\beta-(2 \rightarrow 1)$ linked for fructose units (with a similar structure the inulin forming kestose or nystose), ${ }^{6} \mathrm{~F}$-FOS $\beta-(2 \rightarrow 6)$ linked for fructose units (with the structure similar to levan forming kestose) and ${ }^{6} \mathrm{G}$-FOS what happens when the structure $\beta$ $(2 \rightarrow 6)$ does it link to the fraction glycosyl of the sucrose forming a neokestose or neonystose (Linde et al. 2012).

According to Tian and Karboune (2012), the functional properties of FOSs are directly linked to their chemical structure, in matter, to the fraction hexose, to the polymerization type and the glycoside connections.

The enzyme immobilizations reveal some advantages for industrial applications because the re-utilization, the increase in stability and the use of bioreactors making the separation of the products easier compared to soluble enzyme leading to economical bioprocesses (Silval et al. 2012).

However, based on the results from the specialized literature, it does not exist any work that uses the enzyme inulinase immobilized in activated carbon and sodium alginate for FOS production in aqueous medium.

Based on these aspects, the main focus of this work is to investigate the production of FOS using immobilized inulinases from Aspergillus niger and Kluyveromyces marxianus NRRL Y-7571. For the experiments, free, immobilized, with and without previous treatment in pressurized fluids, inulinases were used as catalysts and a comparison among them could be carried out.

\section{EXPERIMENTAL}

\subsection{Chemical and Enzymes}

The commercial inulinase was obtained from Aspergillus niger (Fructozyme, exoinulinase (EC 3.2.1.80) and endo-inulinase (EC 3.2.1.7)) acquired of Sigma-Aldrich. Noncommercial inulinases were produced from Kluyveromyces marxianus NRRL Y-7571, flowing the methodologies described by Mazutti et al. (2010).

The pure $n$-butane, propane (minimum purity of 99.5\%) were purchased from White Martins S.A. LPG (liquefied petroleum gas) was kindly donated by Petrobras and is constituted 


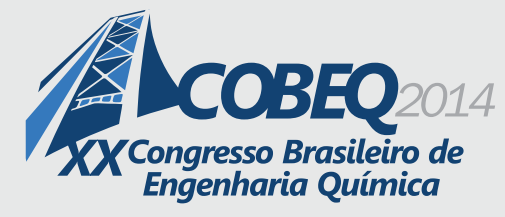

19 a 22 de outubro de 2014

Florianópolis/SC

by a mixture of propane (50.3 wt $\%), n$-butane (28.4 wt $\%)$, isobutane (13.7 wt $\%)$, ethane (wt $\%$ $4.8 \mathrm{wt} \%$ ) and other minor constituents (methane, pentane, isopentane, etc.).

\subsection{Inulinase immobilization}

Firstly, a gel solution was prepared by adding $16.5 \mathrm{~g}$ of distilled water to $0.75 \mathrm{~g}$ of a foodgrade sodium alginate (Vetec, Rio de Janeiro, Brazil), followed by heating at $55{ }^{\circ} \mathrm{C}$ for alginate dissolution and addition of $12.5 \mathrm{~g}$ of sucrose. After gel cooling, $5 \mathrm{~mL}$ of enzymatic solution, $3.5 \mathrm{~mL}$ of glutaraldehyde and $0.75 \mathrm{~g}$ of activated carbon were added to the gel solution (Risso et al. 2012). A peristaltic pump was used for gel pumping and dropping into a solution of $0.2 \mathrm{~mol} / \mathrm{L}$ of sodium chloride in $0.1 \mathrm{~mL} / \mathrm{L}$ of sodium acetate buffer $0.1 \mathrm{M}$ with $3.5 \%$ of glutaraldehyde. This procedure was performed at $10^{\circ} \mathrm{C}$ under agitation.

\subsection{High-pressure treatment of enzymes}

The experimental procedure adopted for enzymes treatment in pressurized fluid consisted, firstly, in adjusting the thermostatic bath to $50{ }^{\circ} \mathrm{C}$, the temperature established in the present work for all experimental runs. Then, the enzymatic preparations $(0.6 \mathrm{~g})$ of immobilized enzyme were loaded into the cell. After this procedure, the system was submitted to pressurization keeping a constant pressurization rate $(10 \mathrm{bar} / \mathrm{min})$. The system was, finally, depressurized at different pre-established rates, according to the experimental design, by a programmed syringe pump piston displacement and the micrometric valve used at lower pressures, near the solvent saturation pressure. The enzymatic activity was determined before (initial activity) and after (final activity) the treatment procedure with pressurized fluids. The experimental condition that led the best results of activity residual were used to pre-treat to enzymes before the FOSs synthesis (Silva et al. 2012, 2013a).

\subsection{Fructooligosaccharides synthesis}

Synthesis was carried out in stirred reactors $(150 \mathrm{rpm})$ with total volume of $10 \mathrm{~mL}$. The operational conditions were sodium acetate buffer $0.1 \mathrm{M}(100 \% \mathrm{w} / \mathrm{v})$, enzyme $(5 \% \mathrm{w} / \mathrm{v})$ and substrate $(60 \% \mathrm{w} / \mathrm{v}$ to sucrose and $20 \% \mathrm{w} / \mathrm{v}$ to inulin). The reaction time for the FOS synthesis was $24 \mathrm{~h}$ at $50{ }^{\circ} \mathrm{C}$, and the kinds of FOS usually produced were: GF2 (kestose); GF3 (nystose), and GF4 (fructosyl nystose) (Silva et al. 2013b).

\subsection{Chromatographic analysis}

The quantification was accomplished in a system of High Performance Liquid Chromatography (HPLC) Agilient 1100 series, detector of refraction index, column model Luna $\mathrm{NH}_{2}(250 \times 4.6 \mathrm{~mm}, 5 \mu \mathrm{m}$ - Phenomenex - it USES), volume of injection of $5 \mu \mathrm{L}$, phase movable 


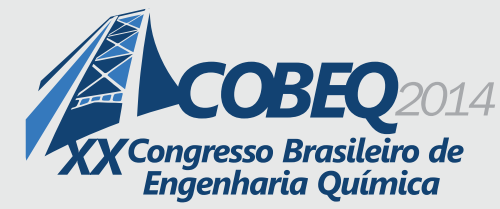

acetonitrile/water (70:30), temperature of the column $20{ }^{\circ} \mathrm{C}$ and temperature of the detector $25{ }^{\circ} \mathrm{C}$ (Silva et al. 2013).

\section{RESULTS AND DISCUSSION}

For the synthesis of FOSs using the commercial inulinase from Aspergillus niger (Table 1), the best results were obtained with the enzyme treated in LPG and using inulin as substrate (GF2-75.97\% and GF4-14.97\%). However, promising values were gotten also using the enzyme treated with the other pressurized fluids. For the treatment with n-butane, the following results were obtained: GF2-53.27\%; GF3-20.95\% and GF4-12.36\% and for propane GF2-59.03\% and GF3-31.31\%. In spite of the income to be loud in the enzyme treated with LPG the formation of the fraction GF4 was not verified, that might have for the little time in which the reaction happened.

In the kestose synthesis starting from immobilized $\beta$-frutofuranosidase obtained starting from the Aureobasidium sp. ATCC 20524, the maximum production obtained by Hayashi et al. (1991) was of $287 \mathrm{~g}$ of kestose starting from $40 \%$ (w/v) of sucrose solution in a time of 168 hours of reaction.

Table 1. Yield of FOS (\%) using the enzyme of Aspergillus niger with inulin and sucrose as substrates.

\begin{tabular}{|c|c|c|c|c|c|c|}
\hline \multirow{3}{*}{ Enzyme preparation } & \multicolumn{3}{|c|}{ Substrates } & & & \\
\hline & \multicolumn{3}{|c|}{ Inulin } & \multicolumn{3}{|c|}{ Sucrose } \\
\hline & GF2 & GF3 & GF4 & GF2 & GF3 & GF4 \\
\hline
\end{tabular}

Immobilized enzyme with treatment in:

\begin{tabular}{|c|c|c|c|c|c|c|}
\hline Propane & 59.03 & 31.31 & ----- & 3.25 & 2.81 & 0.55 \\
\hline$n$-Butane & 53.27 & 20.95 & 12.36 & 4.43 & 4.16 & 2.27 \\
\hline LPG & 75.97 & ----- & 14.97 & 6.05 & ----- & ----- \\
\hline $\begin{array}{l}\text { obilized Enzyme } \\
\text { thout treatment }\end{array}$ & 58.79 & 22.85 & 6.10 & 0.46 & 2.49 & 0.87 \\
\hline Free Enzyme & ----- & ----- & ----- & ----- & ----- & ----- \\
\hline
\end{tabular}

Table 2 presents the results obtained for the synthesis of FOS using the non-commercial inulinases of Kluyveromyces marxianus NRRL Y-7571. It is possible to verify that the incomes were low if compared to the results obtained with Aspergillus niger and other works of the literature. However, the best values for the synthesis were gotten when the enzyme was submitted to the treatment with LPG (GF2-6.4\%; GF3-8.20\% and GF4-6.77\%) with inulin as substrate. This result suggests that the parameters used for the synthesis of FOS in this work are not the 
ideals to obtain high conversions, however the results show that the enzyme is capable to form all of the constituent molecules of FOS (GF2, GF3 and GF4).

Table 2. Yield of FOS using the enzyme of Kluyveromyces marxianus NRRL Y-7571 with inulin and sucrose as substrates.

\begin{tabular}{|c|c|c|c|c|c|c|}
\hline \multirow{3}{*}{ Enzyme preparation } & \multicolumn{3}{|c|}{ Substrates } & & & \\
\hline & \multicolumn{3}{|c|}{ Inulin } & \multicolumn{3}{|c|}{ Sucrose } \\
\hline & GF2 & GF3 & GF4 & GF2 & GF3 & GF4 \\
\hline
\end{tabular}

Immobilized enzyme with treatment in:

\begin{tabular}{|c|c|c|c|c|c|c|}
\hline Propane & ---- & ----- & ----- & 0,39 & ----- & ----- \\
\hline n-Butane & ----- & ----- & ----- & 0,23 & ----- & ----- \\
\hline LPG & ----- & ----- & ----- & ----- & ----- & ----- \\
\hline $\begin{array}{c}\text { Immobilized Enzyme } \\
\text { without treatment }\end{array}$ & 6,4 & 8,2 & 6,77 & & & \\
\hline Free Enzyme & 5,44 & ----- & ----- & ----- & ----- & - \\
\hline
\end{tabular}

Figures 1 to 4 present the products formed in the break of the inulin for synthesis of FOS by Aspergillus niger and Kluyveromyces marxianus NRRL Y 7571, respectively. It is clear starting from these figures that the inulinase does not get to break the inulin molecule totally, in spite of the good reached conversions. To accomplish the mass balance is noticed that the formed products used $15 \%$ of the total of inulin of the medium. The remaining of the inulin is in your original form. For sake of clarity, Figure 5 presents the chromatogram of the standards of (a) fructose; (b) glucose; (c) sucrose; (d) kestose; (e) nystose and (f) fructosyl nystose (Silva et al. 2013).

Figure 1. Composed formed in the synthesis of FOS using Aspergillus niger treated in LPG and inulin as substrate, (a) fructose; (b) glucose; (c) inulin; (d) kestose and (f) fructosyl nystose.

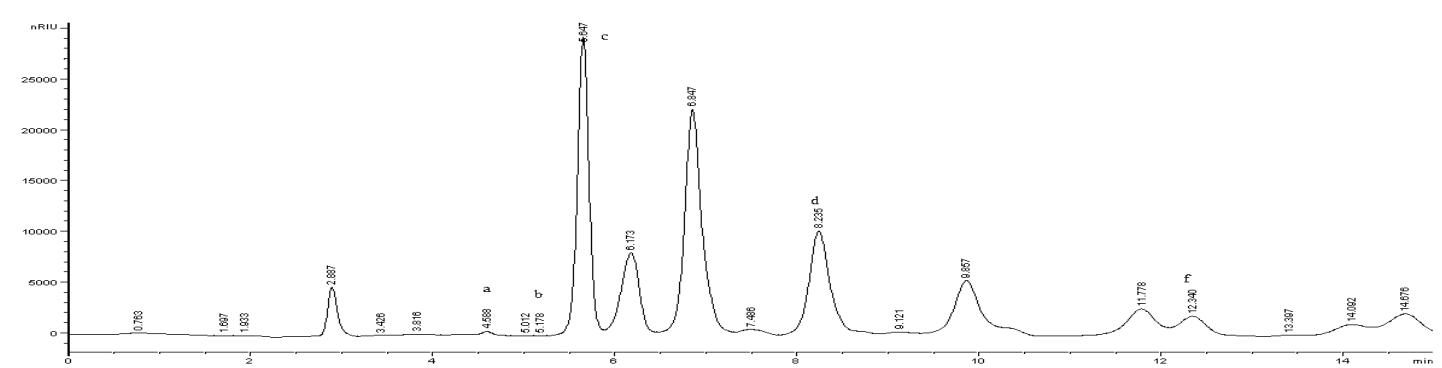

Figure 2. Composed formed in the synthesis of FOS using Aspergillus niger treated in propane and inulin as substrate (c) inulin; (d) kestose and (e) nystose. 


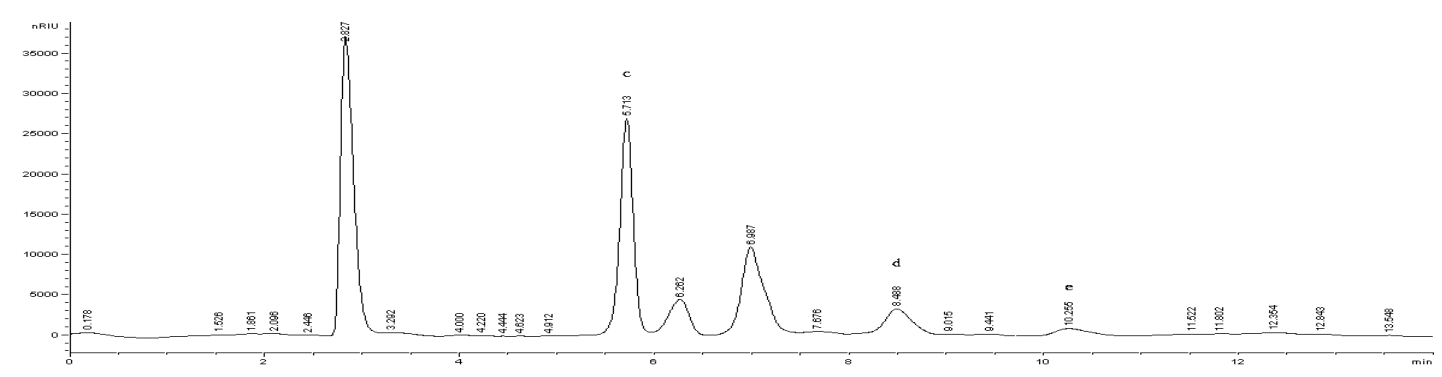

Figure 3. Composed formed in the synthesis of FOS using Aspergillus niger treated in n-butane and inulin as substrate (c) inulin; (d) kestose and (e) nystose.

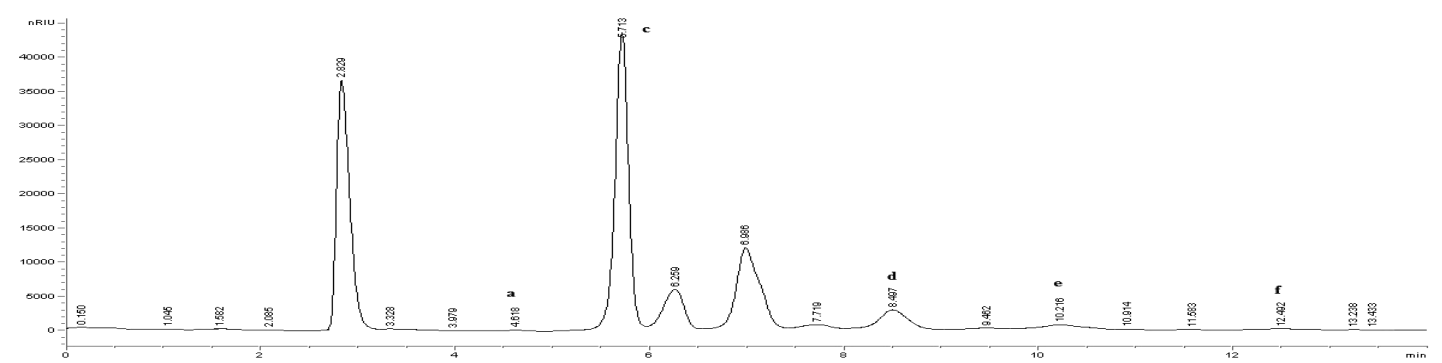

Figure 4. Composed formed in the synthesis of FOS using Kluyveromyces marxianus NRRL Y7571 treated in LPG and inulin as substrate (c) inulin; (d) kestose and (e) nystose.

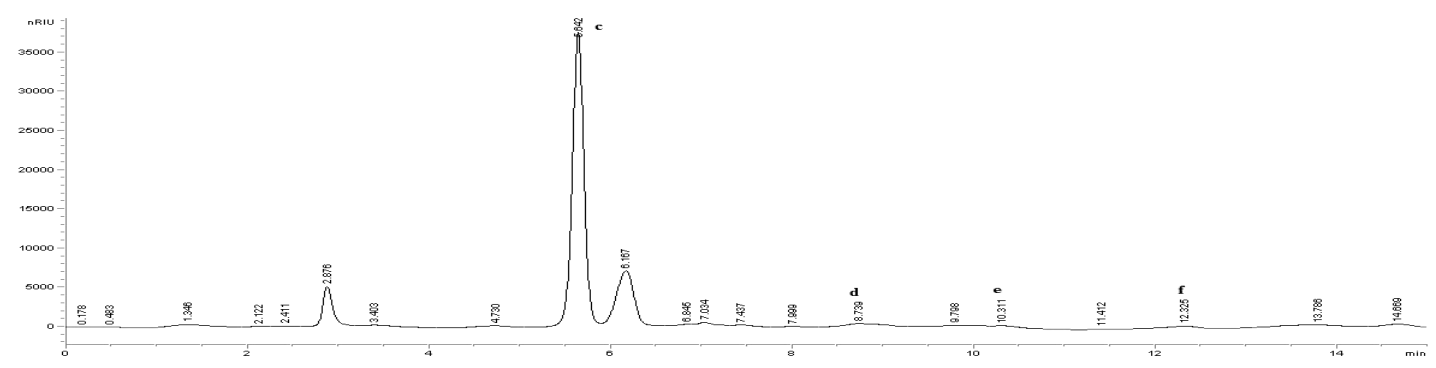

Figure 5. Chromatogram of the standards of (a) fructose; (b) glucose; (c) sucrose; (d) kestose; (e) nystose and (f) fructosyl nystose (Silva et al., 2013).

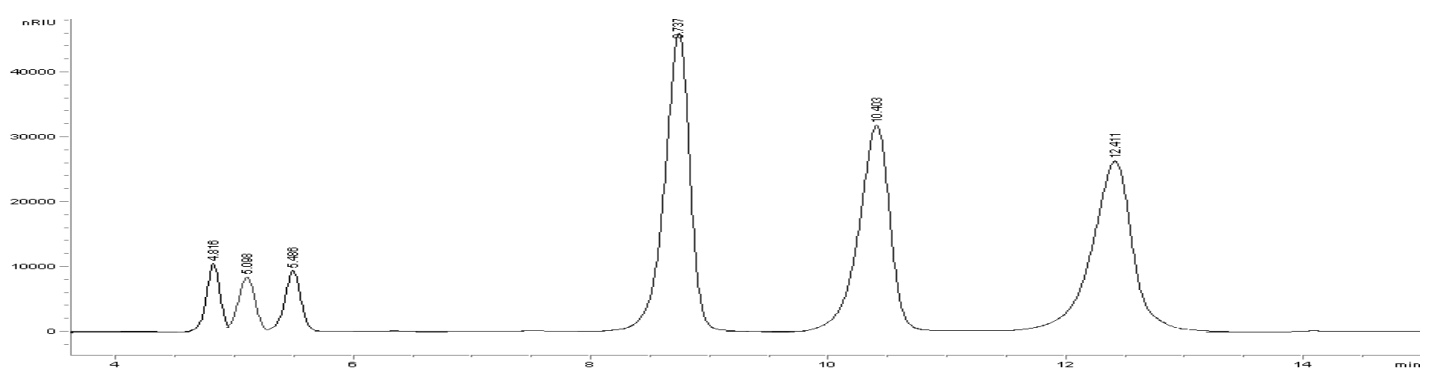

According to the research of Santos and Maugeri (2007), the enzymes can have modifications in the physical and chemical properties after the immobilization process, such as: changes in the enzymatic activity, stability and kinetics. With the intention of elucidating the 
possible modifications caused in the catalytic power of the enzyme after being submitted to the treatment in pressurized fluid, their structures were analyzed by the method of BET.

Table 3 presents the results of the structural analysis of the enzyme of Aspergillus niger and Kluyveromyces marxianus NRRL Y-7571, both immobilized in sodium alginate and activated coal, with and without treatment with pressurized fluids.

From Table 3 it is possible to verify that the changes caused in the structure of the enzyme of Aspergillus niger, after treatment in pressurized fluid, did not affect its catalytic power, however the results obtained for the enzyme of Kluyveromyces marxianus NRRL Y-7571 demonstrate that the modifications in its structural chain affect significantly the catalytic power of the enzyme.

Table 3. Structural characterization of the inulinases.

\begin{tabular}{ccccc}
\hline & Treatment & $\begin{array}{c}\text { Pore } \\
\text { diameter } \\
(\mathrm{nm})\end{array}$ & $\begin{array}{c}\text { Volume of } \\
\text { pore }(\mathrm{mL} / \mathrm{g})\end{array}$ & $\begin{array}{c}\text { Superficial } \\
\text { area BET }\left(\mathrm{m}^{2} / \mathrm{g}\right)\end{array}$ \\
\hline \multirow{4}{*}{. marxianus NRRL } & Propane & 1.63 & 0.003 & 43.38 \\
Y-7571 & $n$-Butane & 4.83 & 0.035 & 2.07 \\
& LPG & 4.83 & 0.03 & 17.09 \\
& & & & 18.75 \\
A. niger & $*$ & 2.73 & 0.024 & 15.82 \\
& Propane & 1.78 & 0.014 & 9.43 \\
& $n$-Butane & 1.62 & 1.95 & 8.86 \\
& LPG & 1.95 & 0.06 & 4.2 \\
\hline
\end{tabular}

*Immobilized enzyme without treatment.

\section{CONCLUSIONS}

Production of FOSs from microbial enzymes using sucrose and inulin as substrates constitute an innovative and lucrative alternative that could support the industry, while satisfying the growing needs of the population for eaten healthy with bioactive compounds. Considering the important implications of the results obtained in the present study, further studies are currently underway in our laboratory to improve FOSs production from Aspergillus niger and Kluyveromyces marxianus NRRL Y- 7571 to make it suitable for future industrial application. 




\section{REFERENCES}

HAYASHI, S., KINOSHITA, J., NONOGUCHI, M., TAKASAKI, Y., IMADA, K. Continuous production of 1-kestose by $\beta$-fructofuranosidase immobilized on shirasu porous glass. Biotech. Letters 13, 395-398, 1991.

LINDE, D., RODRÍGUEZ-COLINAS, B., ESTÉVEZ, M., POVEDA, A., PLOU, F.J., LOBATO, M.F. Analysis of neofructooligosaccharides production mediated by the extracellular $\beta$ - fructofuranosidase from Xanthophyllomyces dendrorhous. Biores. Technol. 123, 234-237, 2012.

MANZONI, M., CAVAZZONI, V. Hydrolysis of Topinambur (Jerusalem Artichoke) Fructans by Extracellular Inulinase of Kluyveromyces marxianus var. bulgaricus. J. Chem. Technol. Biotechnol.199, 311-315, 1992.

MAZUTTI, M.A., ZABOT, G., BONI, G., SKOVRONSKI, A., OLIVEIRA, D., DI LUCCIO, M., RODRIGUES, M.I., TREICHEL, H., MAUGERI, F. Optimization of inulinase production by solid-state fermentation in a packed-bed bioreactor, J. Chem. Technol. Biotechnol. 85, 109114, 2010.

RISSO, F.V.A., MAZUTTI, M.A., TREICHEL, H., COSTA, F., MAUGERI, F., RODRIGUES, M.I. Comparison between systems for synthesis of fructooligosaccharides from sucrose using free inulinase from Kluyveromyces marxianus NRRL Y-7571. Food Bioproc. Technol. 5, 331$337,2012$.

SANTOS, A.M.P., MAUGERI, F. Synthesis of fructooligosaccharides from sucrose using inulinase from Kluyveromyces marxianus. Food Technol. Biotech. 45, 181-186, 2007.

SILVA, M.F., GOLUNSKI, S.M., RIGO, D., MOSSI, V., DI LUCCIO, M., MAZUTTI, M.A., OLIVEIRA, D., OLIVEIRA, J.V., TREICHEL. H. Pressurized Propane: An Alternative Technique to Increase Inulinase Activity, Ind. Biotechnol. 8, 293-299, 2012.

SILVA, M.F., GOLUNSKI, S.M., RIGO, D., MOSSI, V., DI LUCCIO, M., MAZUTTI, M.A., PERGHER, S.B.C., OLIVEIRA, D., OLIVEIRA, J.V., TREICHEL, H. Liquefied petroleum gas as solvent medium for the treatment of immobilized inulinases. J. Chem. Technol. Biotechnol. 91, 54-59, 2013a.

SILVA, M.F., RIGO, D., MOSSI, V., GOLUNSKI, S.M., KUHN, G., DI LUCCIO, M., DALLAGO, R., OLIVEIRA, D., OLIVEIRA, J.V., TREICHEL, H. Enzymatic synthesis of fructooligosaccharides by inulinases from Aspergillus niger and Kluyveromyces marxianus NRRL Y-7571 in aqueous-organic medium. Food Chem. 138, 148-153, $2013 \mathrm{~b}$.

TIAN, F., KARBOUNE, S. Enzymatic synthesis of fructoligosaccharides by levansucrose from Bacillus amyloliquefaciens: Specificity, kinetics and product characterization. J. Mol. Catal. B: Enzymatic. 82, 71-79, 2012.

TREICHEL, H., OLIVEIRA, D., LERIN, L., ASTOLFI, V., MAZUTTI, M.A., DI LUCCIO, M., OLIVEIRA, J.V. A review on the production and partial characterization of microbial inulinases. Global J. Biochem. 3, 7-19, 2012. 